\title{
Actin Filaments Regulate Exocytosis at the Hair Cell Ribbon Synapse
}

\author{
Marie Guillet, Gaston Sendin, Jérôme Bourien, Jean-Luc Puel, and ${ }^{\circledR}$ Régis Nouvian \\ Inserm, Unité Mixte de Recherche 1051, Institute for Neurosciences of Montpellier, 34295 Montpellier Cedex 5, France, and Université Montpellier, 34090 \\ Montpellier, France
}

Exocytosis at the inner hair cell ribbon synapse is achieved through the functional coupling between calcium channels and glutamatefilled synaptic vesicles. Using membrane capacitance measurements, we investigated whether the actin network regulates the exocytosis of synaptic vesicles at the mouse auditory hair cell. Our results suggest that actin network disruption increases exocytosis and that actin filaments may spatially organize a subfraction of synaptic vesicles with respect to the calcium channels.

Key words: cochlea; membrane capacitance; patch-clamp; synaptic release

\section{Significance Statement}

Inner hair cells (IHCs), the auditory sensory cells of the cochlea, release glutamate onto the afferent auditory nerve fibers to encode sound stimulation. To achieve this task, the IHC relies on the recruitment of glutamate-filled vesicles that can be located in close vicinity to the calcium channels or more remotely from them. The molecular determinants responsible for organizing these vesicle pools are not fully identified. Using pharmacological tools in combination with membrane capacitance measurements, we show that actin filament disruption increases exocytosis in IHCs and that actin filaments most likely position a fraction of vesicles away from the calcium channels.

\section{Introduction}

Transmitter release at the first auditory synapse is a fundamental step in transducing acoustic stimulation into a neural message. Incoming acoustic stimulation depolarizes the auditory sensory hair cells, the inner hair cells (IHCs), to elicit calcium influx through voltage-gated calcium channels so that glutamate-filled synaptic vesicles can be released into the synaptic cleft. Activation of postsynaptic glutamate receptors enable the afferent auditory fibers to convey the neural message to the auditory nuclei (Nouvian et al., 2006). Therefore, the synaptic transfer relies on the organization and recruitment of synaptic vesicles with respect to the calcium channels (Brandt et al., 2005; Frank et al., 2010; Wong et al., 2014). Two pools of synaptic vesicles operate at the hair cell ribbon synapse, as shown by presynaptic membrane capacitance measurements

Received Sept. 9, 2015; revised Oct. 29, 2015; accepted Nov. 8, 2015.

Author contributions: M.G., G.S., J.B., J.-L.P., and R.N. designed research; M.G., G.S., J.B., and R.N. performed research; M.G., G.S., J.B., J.-L.P., and R.N. contributed unpublished reagents/analytic tools; M.G., G.S., J.B., and R.N. analyzed data; M.G., G.S., J.B., J.-L.P., and R.N. wrote the paper.

This work was supported by the Agence Nationale pour la Recherche (Grant ANR-13-JSV1-0009-01 to R.N.) and by the Fondation pour I'Avenir. G.S. is a recipient of a Montpellier University postdoctoral fellowship.

The authors declare no competing financial interests.

Correspondence should be addressed to Régis Nouvian, Institute for Neurosciences of Montpellier, Inserm U1051,

80, rue Augustin Fliche, 34295 Montpellier Cedex 5, France. E-mail: regis.nouvian@inserm.fr.

DOI:10.1523/JNEUROSCI.3379-15.2016

Copyright $\odot 2016$ the authors $\quad 0270-6474 / 16 / 360649-06 \$ 15.00 / 0$ and EPSC recordings: the readily releasable pool (RRP), which reflects the fusion of the synaptic vesicles in the vicinity of the calcium channels, and the sustained releasable pool (SRP), which corresponds to the exocytosis of remote vesicles and/or to the resupply of the RRP (Moser and Beutner, 2000; Spassova et al., 2004; Johnson et al., 2005; Schnee et al., 2005; Rutherford and Roberts, 2006; Goutman and Glowatzki, 2007; Li et al., 2009). To date, only the multiple C2-domain otoferlin protein has been shown to regulate the replenishment of the RRP by the SRP in IHCs. In the Pachanga mutant mouse, RRP exocytosis probed by short depolarization is not altered, whereas SRP probed by longer depolarization is gradually affected with the reduction of otoferlin expression (Pangršič et al., 2010). Among the candidates that modulate the synaptic vesicle supply in the nervous system's synapses, actin filaments are known to have a dual role. For example, disruption of actin network increases the frequency of EPSCs in hippocampal neurons (Morales et al., 2000). In contrast, depolymerization of actin filaments (F-actin) slows the vesicle replenishment in the calyx of Held synapse (Sakaba and $\mathrm{Ne}$ her, 2003). Alternatively, synaptic vesicle exocytosis can be completely independent of F-actin (Holt et al., 2003). Although cytoskeleton proteins such as actin are localized near the synaptic ribbon in bullfrog hair cells (Graydon et al., 2011), the role of actin on synaptic vesicle exocytosis at the 

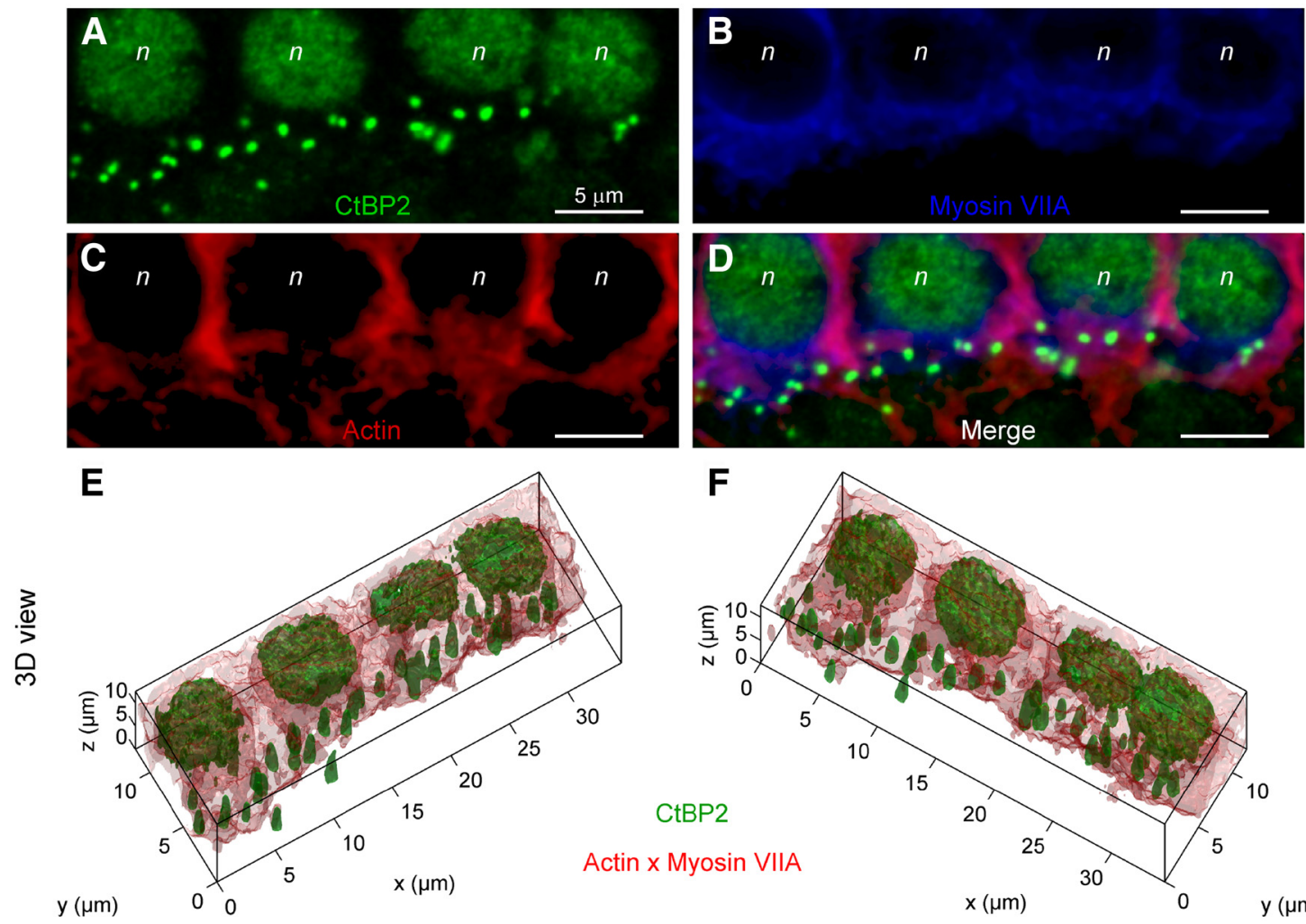

\section{CtBP2}

Actin $x$ Myosin VIIA

Figure 1. Expression of actin in IHCS. $\boldsymbol{A}-\boldsymbol{D}$, Single confocal section through four neighboring IHCS. $\boldsymbol{A}$, Synaptic ribbons were stained with antibody against CtBP2 (green). Note that the IHC nucleus is also labeled due to the nuclear expression of CtBP2. B, IHCs were labeled with anti-myosin VIIA antibody (blue). C, Actin was visualized with rhodamine-conjugated phalloidin (red). $\boldsymbol{D}$, Merged image revealing that actin is localized thoughout the cytoplasm. $n$, Nucleus. Scale bar, $5 \mu \mathrm{m}$. $\boldsymbol{E}$, $\boldsymbol{F}$, Isosurface $3 \mathrm{D}$ reconstruction using the stack of $2 \mathrm{D}$ confocal images (two viewpoints: $\mathrm{E}$, azimuth $=-30^{\circ}$, elevation $=70^{\circ} ; \mathrm{F}$, azimuth $=+30^{\circ}$, elevation $=70^{\circ}$ ). Green, CtBP2/RIBEYE immunofluorescence; red, colocalization of actin and myosin VIIA.

hair cell ribbon synapse has never been determined. Taking advantage of drugs that are known to depolymerize actin filaments, we show that actin regulates the organization of a fraction of vesicles at the hair cell ribbon synapse.

\section{Materials and Methods}

Animals. Swiss mice of either sex were bred and handled following the animal welfare guidelines of the Institut National de la Santé et de la Recherche Médicale (Inserm) and approved by the Ministère Français de l'Agriculture et de la Pêche (authorization \#A3417231).

Immunohistochemistry. Immunohistochemistry and confocal microscopy (Leica TCS SP8-UV) of apical turns were performed as described previously (Sendin et al., 2007) with mouse IgG anti C-terminal binding protein 2 (CtBP2; 1:1000; BD Biosciences) and rabbit polyclonal IgG anti myosin VIIA (1:300; Proteus Biosciences) and the secondary antibodies Alexa Fluor 488-labeled donkey IgG anti-mouse (1:1000; Invitrogen) and Alexa Fluor 647-labeled donkey IgG anti-rabbit (1:1000; Invitrogen). To label F-actin in the cuticular plate and the basolateral membrane, we used phalloidin TRITC (1:1000; Invitrogen).

Electrophysiology. Patch-clamp of IHCs (postnatal day 14-30) from apical coils of freshly dissected organs of Corti were performed as described previously (Nouvian et al., 2011). The extracellular solution contained the following (in $\mathrm{mm}$ ): $105 \mathrm{NaCl}, 35$ tetraethylammonium-Cl (TEA-Cl), $2.8 \mathrm{KCl}, 1 \mathrm{MgCl}_{2}, 10 \mathrm{HEPES}, 1 \mathrm{CsCl}, 2$ $\mathrm{CaCl}_{2}$, and $10 \mathrm{D}$-glucose. The pipette solution for whole-cell experiments contained the following (in mM): 135 Cs-glutamate, 10 TEA$\mathrm{Cl}, 10$ HEPES, $1 \mathrm{MgCl}_{2}, 10$ 4-aminopyridine, $2 \mathrm{Mg}$-ATP, $0.3 \mathrm{Na}$-GTP, and 0.1 EGTA. All solutions were adjusted to $\mathrm{pH} 7.2$ and had osmolarities between 290 and $310 \mathrm{mosmol} / \mathrm{L}$. All chemicals were obtained from Sigma-Aldrich. Latrunculin A, cytochalasin D, and phalloidin were dissolved in DMSO, the final concentration of which in the intracellular solution was $0.25-0.75 \% . \mathrm{Ca}^{2+}$-triggered exocytosis was probed after a $10 \mathrm{~min}$ infusion into IHCs of $20 \mu \mathrm{M}$ latrunculin A, $20 \mu \mathrm{M}$ cytochalasin D, or $100 \mu \mathrm{M}$ phalloidin via the patch-pipette. For control cells, the intracellular solution contained the corresponding DMSO concentration $(0.5 \%$ for latrunculin A and cytochalasin D, $0.25 \%$ for phalloidin, and $0.75 \%$ for latrunculin A plus phalloidin). Control and drug-treated cells were probed over the same time frame for better comparison. Except for the exocytosis amplitude plots against the duration of stimulation (see Fig. 4), all of the controls were pooled together. An EPC-10 amplifier (HEKA Elektronik) controlled by Patchmaster software (HEKA Elektronik) was used for all measurements as described previously (Nouvian et al., 2011). Membrane capacitance jump $\left(\Delta C_{\mathrm{m}}\right)$ was estimated as the difference of the mean $C_{\mathrm{m}}$ over $400 \mathrm{~ms}$ after the end of the depolarization (the initial $250 \mathrm{~ms}$ were skipped) and the mean prepulse capacitance (400 ms). Data analysis was performed using Igor Pro software (Wave-Metrics). Means are expressed as \pm SEM and were compared by Wilcoxon test.

\section{Results}

Actin distribution at the IHC basolateral side

Although the abundant distribution of actin at the apical side of the hair cell-that is, in the stereocilia bundle and the cuticular plate-is well documented, its distribution at the basolateral side of the hair cells has received little attention (Furness et al., 2005). Phalloidin-rhodamin staining and myosin VIIA immunofluorescence show that some actin filaments run below the nucleus into the hair cells' basolateral side (Fig. 1). Although F-actin localized nearby the synaptic area in our confocal microscopy observations, we did not detect enrichment near the synaptic ribbons labeled with antiCtBP2 antibody. Together with the large expression of actin at 
A

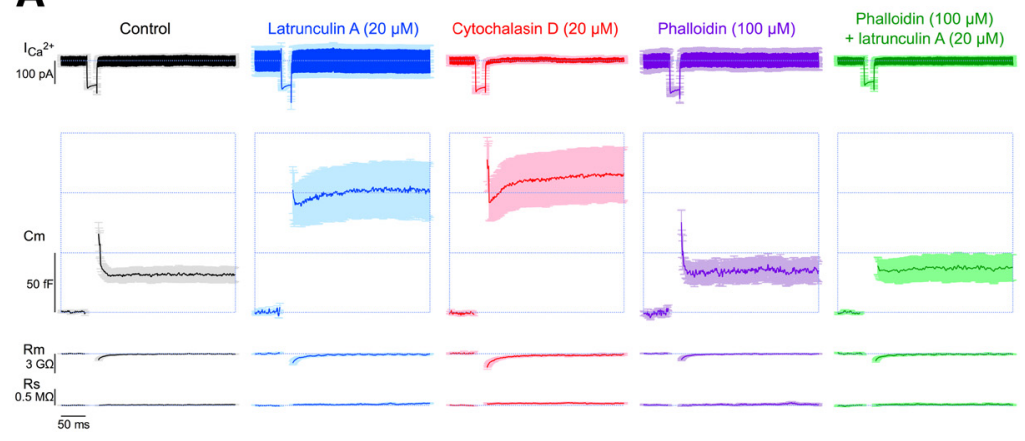

B

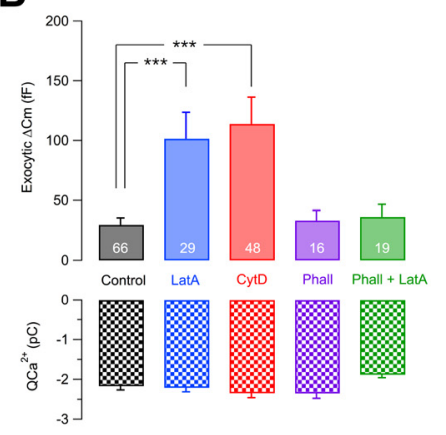

Figure 2. Actin network depolymerization increases exocytosis. $A$, Whole-cell $\mathrm{Ca}^{2+}$ current $\left(\mathrm{ICa}^{2+}\right)$, membrane capacitance $\left(C_{\mathrm{m}}\right)$, membrane resistance $\left(R_{\mathrm{m}}\right)$, and series resistance $\left(R_{s}\right)$ average traces. Data were recorded from IHCs after 10 min infusion with $20 \mu \mathrm{m}$ latrunculin $\mathrm{A}, 20 \mu \mathrm{m}$ cytochalasin $\mathrm{D}, 100 \mu \mathrm{m}$ phalloidin, or $100 \mu \mathrm{m}$ phalloidin plus $20 \mu \mathrm{m}$ latrunculin

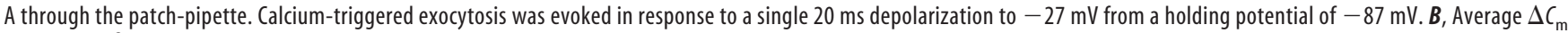
(top) and $\mathrm{Ca}^{2+}$ charges (bottom) evoked by 20 ms depolarization after 10 min infusion of latrunculin A (LatA, $20 \mu \mathrm{M}$ ), cytochalasin D (CytD, $\left.20 \mu \mathrm{M}\right)$, phalloidin (Phall, $100 \mu \mathrm{M}$ ), or phalloidin plus latrunculin A (Phall, $100 \mu \mathrm{M}+$ LatA, $20 \mu \mathrm{m}$ ). All of the controls (black) are pooled together. Only one depolarization step was evoked per IHC and the numbers of IHCs recorded are indicated in white. ${ }^{* * *} p<0.001$.

A

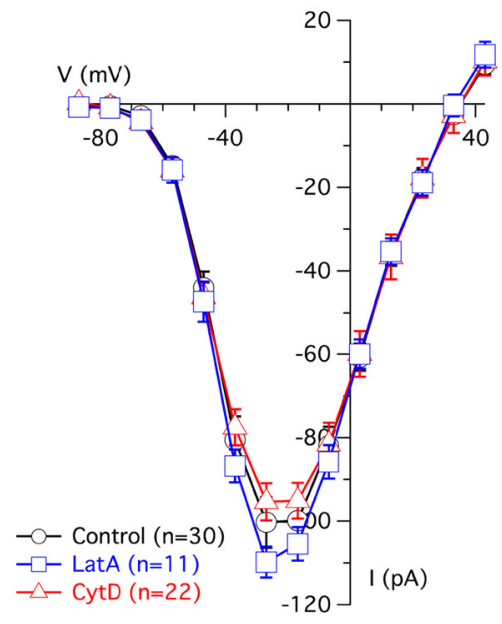

B

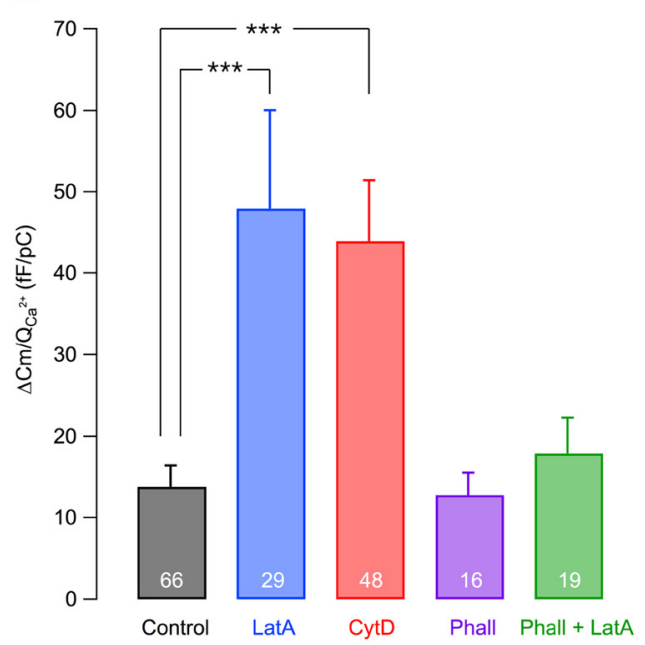

Figure 3. Actin network depolymerization does not alter IHC calcium influx. $A, \mathrm{Ca}^{2+}$ current $\mathrm{I} / \mathrm{V}$ relationships of $\mathrm{HHC}$ infused for 10 min with latrunculin $A(L a t A, 20 \mu \mathrm{M})$ and cytochalasin D (CytD, $20 \mu \mathrm{M})$. B, Release efficiency of IHCs treated with latrunculin $A$ (LatA, $20 \mu \mathrm{m}$ ), cytochalasin D (CytD, $20 \mu \mathrm{m}$ ), phalloidin (Phall, $100 \mu \mathrm{M}$ ), and phalloidin plus latrunculin A (Phall, $100 \mu \mathrm{M}+$ LatA, $20 \mu \mathrm{M}$ ). Release efficiency was measured as the $\Delta C_{\mathrm{m}} / \mathrm{QCa}^{2+}$ ratio from Figure $2 B$. ${ }^{* * *} p<0.001$.

the apical side, this result suggests that actin filaments also populate the basolateral side of the hair cells.

\section{Actin depolymerization increases exocytosis}

The regulation of calcium-triggered exocytosis by the actin network was investigated using drugs that are known to depolymerize actin filaments. We first infused latrunculin $\mathrm{A}$, a drug that sequesters the G-actin monomer and therefore leads to the depolymerization of actin, into hair cells for $10 \mathrm{~min}$. In response to a $20 \mathrm{~ms}$ depolarizing pulse to $-27 \mathrm{mV}$, infusion of $20 \mu \mathrm{M}$ latrunculin A increased exocytosis, probed by capacitance measurements as a proxy of synaptic vesicle fusion (Fig. 2;29.6 $\pm 5.7 \mathrm{fF}$ for control cells vs $101.5 \pm 22.1 \mathrm{fF}$ for latrunculin A-treated cells; $p<0.001)$. To confirm these results, we then probed the effect of cytochalasin $\mathrm{D}$, which caps the barbed end of F-actin to depolymerize the actin filaments (Fig. 2). Here again, we found out that infusion of $20 \mu \mathrm{M}$ cytochalasin D for $10 \mathrm{~min}$ increased the synaptic vesicle exocytosis evoked by the $20 \mathrm{~ms}$ depolarization step $(29.6 \pm 5.7 \mathrm{fF}$ vs $113.8 \pm$ $22.5 \mathrm{fF}$ for control and cytochalasin D-treated cells, respectively; $p<$
0.001). Although $100 \mu \mathrm{M}$ phalloidin, which stabilizes actin, alone did not significantly affect IHC secretion $(33.2 \pm 8.5 \mathrm{fF})$, coapplication of $20 \mu \mathrm{M}$ latrunculin A together with $100 \mu \mathrm{M}$ phalloidin $(36.3 \pm 10.4 \mathrm{fF})$ prevented the increase of synaptic vesicle exocytosis elicited by latrunculin A alone (Fig. 2). Together, these effects suggest that the actin filament network regulates neurotransmitter release at the hair cell ribbon synapse.

Actin depolymerization does not alter
the calcium current amplitude
The facilitating effect of actin depoly-
merization may result from an increase
of the calcium current. However, the
calcium current amplitude did not show
any significant difference between con-
trol and latrunculin A- or cytochalasin
D-treated cells (calcium peak current
$-100.3 \pm 6.1$ pA, $-109.8 \pm 3.7$ and
$-95.4 \pm 4.5$ pA for control, latrunculin
A, and cytochalasin D, respectively; Fig.
$3 A$ ). In addition, a higher release efficiency given by the ratio of the capacitance jump over the corresponding calcium charge was observed in cells exposed to latrunculin A as well as cytochalasin D (Fig. 3B; $13.8 \pm 2.6$ $\mathrm{fF} / \mathrm{QCa}^{2+}$ vs $47.9 \pm 12.1 \mathrm{fF} / \mathrm{QCa}^{2+}$ and $43.9 \pm 7.5 \mathrm{fF} / \mathrm{QCa}^{2+}$ for control, latrunculin A and cytochalasin-treated cells, respectively; $p<0.001)$.

\section{Restricted effect of actin depolymerization on exocytosis}

Next, we investigated whether actin filament network disruption also affects SRP or the RRP-SRP relationship. To do so, we probed exocytosis evoked by steps of different duration because short durations of stimulation mostly recruit exocytosis of the RRP, whereas longer pulses mobilize mainly the synaptic vesicles belonging to the SRP (Nouvian et al., 2006). The exocytosis plot against the time duration of the stimulation shows that latrunculin A $(20 \mu \mathrm{M})$ or cytochalasin D (20 $\mu \mathrm{M})$ mainly affected exocytosis evoked by a $20 \mathrm{~ms}$ step depolarization, leaving the secretion elicited by shorter ( $5 \mathrm{~ms}$, con- 
A

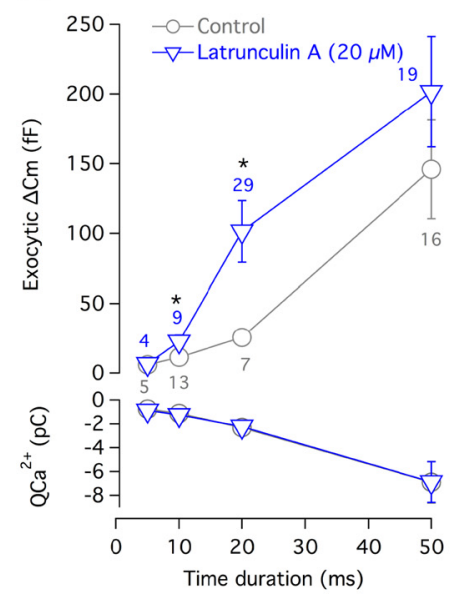

B

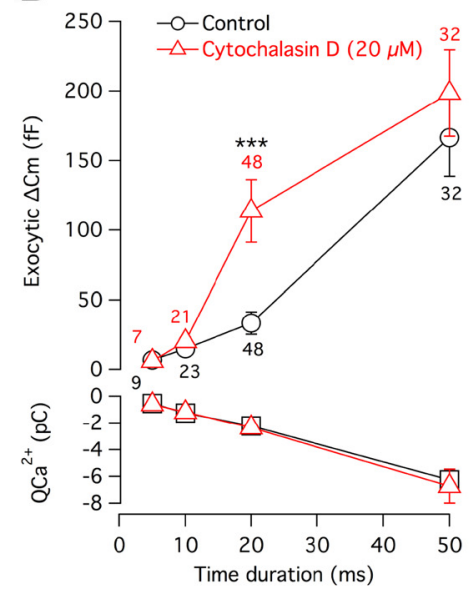

C
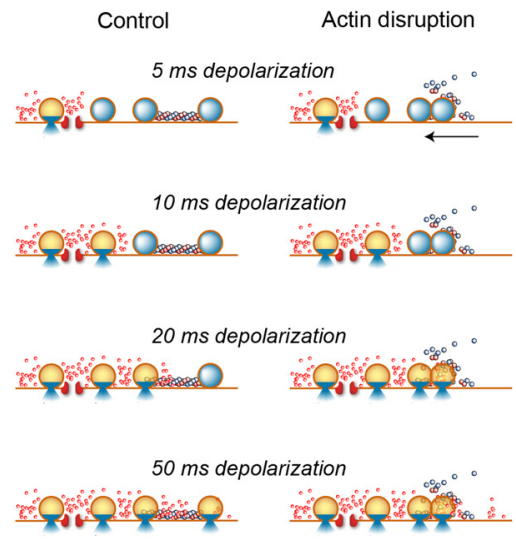

Figure 4. The facilitating effect of actin depolymerization is limited to $20 \mathrm{~ms}$ pulse duration. $\boldsymbol{A}, \boldsymbol{B}$, Exocytic $\Delta \boldsymbol{C}_{\mathrm{m}}$ (top) and the corresponding $\mathrm{Ca}^{2+}$ current integrals ( $Q C^{2}{ }^{2+}$, bottom) are represented versus the duration of depolarization for control IHCs (black) or infused with latrunculin A (LatA, $20 \mu \mathrm{m} ; \boldsymbol{A}$ ) or cytochalasin D (CytD, $20 \mu \mathrm{m} ; \boldsymbol{B}$ ). Calcium-triggered exocytosis was evoked in response to a single depolarization to $-27 \mathrm{mV}$ from a holding potential of $-87 \mathrm{mV}$. Only one depolarization step was evoked per IHC. Numbers of IHCs recorded are indicated for each depolarization step. ${ }^{*} p<0.05 ;{ }^{* * *} p<0.001$. C, Hypothetical mechanism underlying the increase of exocytosis after actin filament depolymerization. In this scenario, actin filaments organize a fraction of synaptic vesicles with respect to the calcium channels. Disruption of actin leads to the displacement of a group of vesicles toward the calcium channels (arrow) so that these vesicles, which are normally recruited in response to a 50 ms pulse duration in the control condition, are mixed with the ones fusing within 20 ms. Alternative scenarios are possible (see Discussion).

trol: $6.8 \pm 1.6 \mathrm{fF}$; latrunculin A: $6.6 \pm 0.5 \mathrm{fF}$; cytochalasin D: $5.9 \pm 1.1 \mathrm{fF}$ ) and longer (50 ms; control: $166.5 \pm 27.7 \mathrm{fF}$; latrunculin A: $201.6 \pm 39.5 \mathrm{fF}$; cytochalasin D: $198.5 \pm 31.1$ fF) pulses unchanged (Fig. 4). Because the exocytosis measurement assay used in our study is cumulative, the observed effect for a $20 \mathrm{~ms}$ pulse duration suggests that a fraction of vesicles normally recruited in response to a $50 \mathrm{~ms}$ pulse duration becomes available for release at a shorter pulse (20 ms) after the actin filament disruption.

\section{Discussion}

In our study, depolymerization of actin filaments increased IHC secretion. However, this effect was prevalent for an intermediate duration of stimuli (20 ms), excluding a facilitatory action on the RRP. We propose that the actin filament network might organize the location of a fraction of the SRP synaptic vesicles with respect to calcium channels.

\section{Actin and hair cell exocytosis}

In most of the studies, the role of the actin network has been inferred using drugs known to disrupt actin filaments (Casella et al., 1981; Spector et al., 1983; Cooper, 1987). Here, the comparable effects of latrunculin A and cytochalasin D support a similar mechanism of action: to inhibit actin polymerization. In addition, we validated the drug's specificity of action by coinfusing latrunculin A and phalloidin (an actin network stabilizer), a manipulation that prevented the action of latrunculin A and resulted in normal exocytosis. However, phalloidin itself does not alter the calcium-triggered exocytosis, suggesting that the actin network does not act in a dynamic fashion on secretion. Although actin filaments populate the hair cell cytoplasm (our study and Furness et al., 2005), synapsin is absent in hair cells (Layton et al., 2005; McLean et al., 2009; Uthaiah and Hudspeth, 2010). Synapsin is a synaptic protein known to interact with actin to cluster and mobilize a reserve pool of vesicles upon dephosphorylation and phosphorylation cycling, respectively (Greengard et al., 1993). Therefore, the lack of synapsin in hair cells calls for alternative mechanisms of action.

\section{Potential mechanisms for the increase of exocytosis after actin disruption}

The increase of exocytosis in response to a $20 \mathrm{~ms}$ pulse duration indicates that a higher number of vesicles undergo fusion during this depolarizing step. The increase in cell capacitance may therefore reflect the addition of a newly arrived vesicle pool, which is not recruited in normal conditions or the premature exocytosis of preexisting vesicles. In the scenario of additional vesicles being added to the preexisting pool, the amplitude of exocytosis after disruption should still be higher at $50 \mathrm{~ms}$ depolarization step because of the cumulative nature of our measurement of exocytosis. However, there is no difference between control and latrunculin A- or cytochalasin D-treated cells for longer depolarization pulses. This result can be explained if a subfraction of the SRP, which is normally recruited at $50 \mathrm{~ms}$ step depolarization, becomes available in advance and is engaged in release at a shorter step depolarization once the actin network has been disrupted. Different mechanisms may account for the change in stimulation-secretion coupling. For example, actin may set a position between the synaptic vesicles and the calcium channels to prevent a premature priming step of the vesicles (i.e., to become competent for fusion) by being closer to the calcium source (Voets, 2000; Neher and Sakaba, 2008; Lee et al., 2012, 2013). However, we cannot completely exclude that actin disruption converts reluctant synaptic vesicles into releasing vesicles within a spatially mixed population of vesicles (Sankaranarayanan et al., 2003).

In the hypothesis in which the SRP vesicles are remote from the calcium channels (Pangršič et al., 2015), actin filaments could slow down or prevent the movement of the synaptic vesicles toward the release sites, similar to chromaffin cells, in which the actin network forms a submembrane matrix that impedes morphological docking of granules to the plasma membrane (Vitale et al., 1995; Toonen et al., 2006). Together with an actin-free domain close to the synaptic ribbon, such a mechanism would allow the vesicles to quickly attach to the ribbon and avoid a traffic jam of vesicles for synaptic release. In the case of prolonged stimulation, calcium buildup at the synaptic region would favor 
the depolymerization of actin because this process is calcium dependent (Bennett and Weeds, 1986), thus increasing the number of synaptic vesicles available for transmitter release.

If the resupply of the RRP by the SRP becomes faster after actin depolymerization, then the high rate of the RRP replenishment (Moser and Beutner, 2000; Spassova et al., 2004; Cho et al., 2011) may lead to SRP exhaustion (Voets et al., 1999), so longer pulses do not elicit an increase in exocytosis as we observed in our recordings. Therefore, the actin network might provide an efficient means for hair cells to operate vesicle replenishment at a high rate (Moser and Beutner, 2000; Spassova et al., 2004; Cho et al., 2011). In addition, our recordings at room temperature most probably underestimate the relevance of actin in vesicle trafficking because actin depolymerization, synaptic replenishment, and hair cell exocytosis are all temperature dependent (Wendel and Dancker, 1986; Kushmerick et al., 2006; Nouvian, 2007). Conversely, calcium channels themselves might undergo a higher mobility after the actin network disruption, as has been shown in cone and rod photoreceptors (Mercer et al., 2011). In this case, the extension of the area where calcium channels are confined could lead to the dispersion of calcium channels and enable the fusion of remote vesicles. According to this framework, the interaction between actin filaments and $\operatorname{Cav} \beta 2$, an auxiliary subunit of the Cav1.3 channel expressed in the IHCs (Neef et al., 2009), has been reported recently (Stölting et al., 2015).

Finally, actin depolymerization may affect the spatial organization of organelles within the presynaptic terminal such as the endoplasmic reticulum (Joensuu et al., 2014). Bringing a local calcium source close to the active zone could amplify the calcium concentration through a calcium-induced calcium-release process leading to a larger secretion (Kennedy and Meech, 2002; Schnee et al., 2011; Castellano-Muñoz et al., 2015). Although we favor a change in the distance between synaptic vesicles and calcium channels because actin has been shown to have a structural role in other synapses (Cole et al., 2000; Cingolani and Goda, 2008), future examinations of the synaptic ultrastructure and calcium channel dynamics after actin disruption are required to test the above hypotheses.

\section{References}

Bennett J, Weeds A (1986) Calcium and the cytoskeleton. Br Med Bull 42: 385-390. Medline

Brandt A, Khimich D, Moser T (2005) Few CaV1.3 channels regulate the exocytosis of a synaptic vesicle at the hair cell ribbon synapse. J Neurosci 25:11577-11585. CrossRef Medline

Casella JF, Flanagan MD, Lin S (1981) Cytochalasin D inhibits actin polymerization and induces depolymerization of actin filaments formed during platelet shape change. Nature 293:302-305. CrossRef Medline

Castellano-Muñoz M, Schnee ME, Ricci AJ (2015) Calcium-induced calcium release supports recruitment of synaptic vesicles in auditory hair cells. J Neurophysiol. In press.

Cho S, Li GL, von Gersdorff H (2011) Recovery from short-term depression and facilitation is ultrafast and $\mathrm{Ca} 2+$ dependent at auditory hair cell synapses. J Neurosci 31:5682-5692. CrossRef Medline

Cingolani LA, Goda Y (2008) Actin in action: the interplay between the actin cytoskeleton and synaptic efficacy. Nat Rev Neurosci 9:344-356. CrossRef Medline

Cole JC, Villa BR, Wilkinson RS (2000) Disruption of actin impedes transmitter release in snake motor terminals. J Physiol 525:579-586. CrossRef Medline

Cooper JA (1987) Effects of cytochalasin and phalloidin on actin. J Cell Biol 105:1473-1478. CrossRef Medline

Frank T, Rutherford MA, Strenzke N, Neef A, Pangršič T, Khimich D, Fejtova A, Fetjova A, Gundelfinger ED, Liberman MC, Harke B, Bryan KE, Lee A, Egner A, Riedel D, Moser T (2010) Bassoon and the synaptic ribbon organize $\mathrm{Ca}^{2}+$ channels and vesicles to add release sites and promote refilling. Neuron 68:724-738. CrossRef Medline
Furness DN, Katori Y, Mahendrasingam S, Hackney CM (2005) Differential distribution of beta- and gamma-actin in guinea-pig cochlear sensory and supporting cells. Hear Res 207:22-34. CrossRef Medline

Goutman JD, Glowatzki E (2007) Time course and calcium dependence of transmitter release at a single ribbon synapse. Proc Natl Acad Sci U S A 104:16341-16346. CrossRef Medline

Graydon CW, Cho S, Li GL, Kachar B, von Gersdorff H (2011) Sharp Ca2+ nanodomains beneath the ribbon promote highly synchronous multivesicular release at hair cell synapses. J Neurosci 31:16637-16650. CrossRef Medline

Greengard P, Valtorta F, Czernik AJ, Benfenati F (1993) Synaptic vesicle phosphoproteins and regulation of synaptic function. Science 259: 780-785. CrossRef Medline

Holt M, Cooke A, Wu MM, Lagnado L (2003) Bulk membrane retrieval in the synaptic terminal of retinal bipolar cells. J Neurosci 23:1329-1339. Medline

Joensuu M, Belevich I, Rämö O, Nevzorov I, Vihinen H, Puhka M, Witkos TM, Lowe M, Vartiainen MK, Jokitalo E (2014) ER sheet persistence is coupled to myosin 1c-regulated dynamic actin filament arrays. Mol Biol Cell 25:1111-1126. CrossRef Medline

Johnson SL, Marcotti W, Kros CJ (2005) Increase in efficiency and reduction in $\mathrm{Ca} 2+$ dependence of exocytosis during development of mouse inner hair cells. J Physiol 563:177-191. CrossRef Medline

Kennedy HJ, Meech RW (2002) Fast Ca2+ signals at mouse inner hair cell synapse: a role for $\mathrm{Ca} 2+$-induced Ca2+ release. J Physiol 539:15-23. CrossRef Medline

Kushmerick C, Renden R, von Gersdorff H (2006) Physiological temperatures reduce the rate of vesicle pool depletion and short-term depression via an acceleration of vesicle recruitment. J Neurosci 26:1366-1377. CrossRef Medline

Layton MG, Robertson D, Everett AW, Mulders WH, Yates GK (2005) Cellular localization of voltage-gated calcium channels and synaptic vesicleassociated proteins in the guinea pig cochlea. J Mol Neurosci 27:225-244. CrossRef Medline

Lee JS, Ho WK, Lee SH (2012) Actin-dependent rapid recruitment of reluctant synaptic vesicles into a fast-releasing vesicle pool. Proc Natl Acad Sci U S A 109:E765-E774. CrossRef Medline

Lee JS, Ho WK, Neher E, Lee SH (2013) Superpriming of synaptic vesicles after their recruitment to the readily releasable pool. Proc Natl Acad Sci U S A 110:15079-15084. CrossRef Medline

Li GL, Keen E, Andor-Ardó D, Hudspeth AJ, von Gersdorff H (2009) The unitary event underlying multiquantal EPSCs at a hair cell's ribbon synapse. J Neurosci 29:7558-7568. CrossRef Medline

McLean WJ, Smith KA, Glowatzki E, Pyott SJ (2009) Distribution of the $\mathrm{Na}, \mathrm{K}-\mathrm{ATPase}$ alpha subunit in the rat spiral ganglion and organ of corti. J Assoc Res Otolaryngol 10:37-49. CrossRef Medline

Mercer AJ, Chen M, Thoreson WB (2011) Lateral mobility of presynaptic L-type calcium channels at photoreceptor ribbon synapses. J Neurosci 31:4397-4406. CrossRef Medline

Morales M, Colicos MA, Goda Y (2000) Actin-dependent regulation of neurotransmitter release at central synapses. Neuron 27:539-550. CrossRef Medline

Moser T, Beutner D (2000) Kinetics of exocytosis and endocytosis at the cochlear inner hair cell afferent synapse of the mouse. Proc Natl Acad Sci U S A 97:883-888. CrossRef Medline

Neef J, Gehrt A, Bulankina AV, Meyer AC, Riedel D, Gregg RG, Strenzke N, Moser T (2009) The Ca2 + channel subunit beta2 regulates Ca2 + channel abundance and function in inner hair cells and is required for hearing. J Neurosci 29:10730-10740. CrossRef Medline

Neher E, Sakaba T (2008) Multiple roles of calcium ions in the regulation of neurotransmitter release. Neuron 59:861-872. CrossRef Medline

Nouvian R (2007) Temperature enhances exocytosis efficiency at the mouse inner hair cell ribbon synapse. J Physiol 584:535-542. CrossRef Medline

Nouvian R, Beutner D, Parsons TD, Moser T (2006) Structure and function of the hair cell ribbon synapse. J Membr Biol 209:153-165. CrossRef Medline

Nouvian R, Neef J, Bulankina AV, Reisinger E, Pangršič T, Frank T, Sikorra S, Brose N, Binz T, Moser T (2011) Exocytosis at the hair cell ribbon synapse apparently operates without neuronal SNARE proteins. Nat Neurosci 14:411-413. CrossRef Medline

Pangršič T, Lasarow L, Reuter K, Takago H, Schwander M, Riedel D, Frank T, Tarantino LM, Bailey JS, Strenzke N, Brose N, Müller U, Reisinger E, 
Moser T (2010) Hearing requires otoferlin-dependent efficient replenishment of synaptic vesicles in hair cells. Nat Neurosci 13:869-876. CrossRef Medline

Pangršič T, Gabrielaitis M, Michanski S, Schwaller B, Wolf F, Strenzke N, Moser T (2015) EF-hand protein Ca2+ buffers regulate Ca2+ influx and exocytosis in sensory hair cells. Proc Natl Acad Sci U S A 112: E1028-E1037. CrossRef Medline

Rutherford MA, Roberts WM (2006) Frequency selectivity of synaptic exocytosis in frog saccular hair cells. Proc Natl Acad Sci U S A 103: 2898-2903. CrossRef Medline

Sakaba T, Neher E (2003) Involvement of actin polymerization in vesicle recruitment at the calyx of Held synapse. J Neurosci 23:837-846. Medline

Sankaranarayanan S, Atluri PP, Ryan TA (2003) Actin has a molecular scaffolding, not propulsive, role in presynaptic function. Nat Neurosci 6: 127-135. CrossRef Medline

Schnee ME, Lawton DM, Furness DN, Benke TA, Ricci AJ (2005) Auditory hair cell-afferent fiber synapses are specialized to operate at their best frequencies. Neuron 47:243-254. CrossRef Medline

Schnee ME, Santos-Sacchi J, Castellano-Muñoz M, Kong JH, Ricci AJ (2011) Calcium-dependent synaptic vesicle trafficking underlies indefatigable release at the hair cell afferent fiber synapse. Neuron 70:326-338. CrossRef Medline

Sendin G, Bulankina AV, Riedel D, Moser T (2007) Maturation of ribbon synapses in hair cells is driven by thyroid hormone. J Neurosci 27: 3163-3173. CrossRef Medline

Spassova MA, Avissar M, Furman AC, Crumling MA, Saunders JC, Parsons TD (2004) Evidence that rapid vesicle replenishment of the synaptic ribbon mediates recovery from short-term adaptation at the hair cell afferent synapse. J Assoc Res Otolaryngol 5:376-390. CrossRef Medline
Spector I, Shochet NR, Kashman Y, Groweiss A (1983) Latrunculins: novel marine toxins that disrupt microfilament organization in cultured cells. Science 219:493-495. CrossRef Medline

Stölting G, de Oliveira RC, Guzman RE, Miranda-Laferte E, Conrad R, Jordan N, Schmidt S, Hendriks J, Gensch T, Hidalgo P (2015) Direct interaction of $\mathrm{CaV} \beta$ with actin up-regulates L-type calcium currents in HL-1 cardiomyocytes. J Biol Chem 290:4561-4572. CrossRef Medline

Toonen RF, Kochubey O, de Wit H, Gulyas-Kovacs A, Konijnenburg B, Sørensen JB, Klingauf J, Verhage M (2006) Dissecting docking and tethering of secretory vesicles at the target membrane. EMBO J 25:3725-3737. CrossRef Medline

Uthaiah RC, Hudspeth AJ (2010) Molecular anatomy of the hair cell's ribbon synapse. J Neurosci 30:12387-12399. CrossRef Medline

Vitale ML, Seward EP, Trifaró JM (1995) Chromaffin cell cortical actin network dynamics control the size of the release-ready vesicle pool and the initial rate of exocytosis. Neuron 14:353-363. CrossRef Medline

Voets T (2000) Dissection of three Ca2+-dependent steps leading to secretion in chromaffin cells from mouse adrenal slices. Neuron 28:537-545. CrossRef Medline

Voets T, Neher E, Moser T (1999) Mechanisms underlying phasic and sustained secretion in chromaffin cells from mouse adrenal slices. Neuron 23:607-615. CrossRef Medline

Wendel H, Dancker P (1986) Kinetics of actin depolymerization: influence of ions, temperature, age of F-actin, cytochalasin B and phalloidin. Biochim Biophys Acta 873:387-396. CrossRef Medline

Wong AB, Rutherford MA, Gabrielaitis M, Pangršič T, Göttfert F, Frank T, Michanski S, Hell S, Wolf F, Wichmann C, Moser T (2014) Developmental refinement of hair cell synapses tightens the coupling of Ca2+ influx to exocytosis. EMBO J 33:247-264. Medline 